\title{
A kénosis da Trindade
}

\author{
Pe. Donizete José Xavier ${ }^{1}$
}

\section{RESUMO:}

Este texto pretende desenvolver em linhas gerais, o delicado e audacioso tema da kénosis trinitária. Sabe-se que metodologicamente é preciso ter como ponto de partida para tal reflexão, os encaminhamentos atuais da pneumatológica trinitária juntamente com a consciência que a experiência de fé sempre adquire no Espírito

Palavras-chave: Kénosis trinitá-

\begin{abstract}
:
This text intends to develop in general lines, the delicate and audacius theme of trinitarian kenosis. Know that methodologically, for such a reflection it's necessary to have as a starting point, the actual directives of trinitarian pneumatology, together with the conscience that an experience of faith acquires in the Spirit.

Key-words: Trinitarian kenosis, Faith, Spirit.
\end{abstract} ria, fé, Espírito.

\section{INTRODUÇÃO}

Este texto pretende desenvolver em linhas gerais, o delicado e audacioso tema da kénosis trinitária. Sabe-se que metodologicamente é preciso ter como ponto de partida para tal reflexão, os encaminhamentos atuais da pneumatológica trinitária juntamente com a consciência que a experiência de

\footnotetext{
1 Licenciado em Filosofia pela Faculdade Associada do Ipiranga e mestre em teologia pela Faculdade Nossa Senhora Assunção. Professor auxiliar de Teologia Sistemática na Faculdade Nossa Senhora Assunção e na Escola de Teologia Dominicana. Tutor de Antropologia Teológica no Centro Universitário Claretiano. Professor de Teologia Dogmática no Centro de Espiritualidade Teresiano. Assessor de Teologia Dogmática na CRB de São Paulo e Núcleo de Barretos.
} 
fé sempre adquire no Espírito. Estas duas realidades constituem o âmbito propicio para conhecer e encontrar ao Deus cristão, que se revela na história. Como já afirmava São Gregório Nazianzeno: "não há outro meio para conhecer a Deus que viver no Espírito Santo". O Espírito Santo, tal como se contempla na teologia das missões revela a Deus como comunhão, compartimento e espaço para o outro, sendo ele mesmo no seio da Trindade o que tem revelado. Ele é expressão pessoal do amor que se doa e se recebe. É Pessoa-Dom-que-se-dá, amor expandido. Neste ritmo próprio do Espírito Santo no ser de Deus e na história da salvação, a teologia contemporânea tem compreendido a figura do Espírito Santo como mistério de saída de si e de alteridade. Este ritmo do Espírito tem sido ressaltado pela atual teologia pneumatológica, como kénosis do Espírito Santo. No desdobramento da teologia trinitária a kénosis do Espírito Santo tem sido compreendida como kénosis mesma da Trindade.

Percorrendo este caminho teológico, verificar-se-á que o princípio material da doutrina da Trindade é a kénosis e o princípio formal da teologia da kénosis é a doutrina da Trindade. Nesta elaboração metodológica é preciso resgatar uma linguagem trinitária para chegar a plena compreensão da kénosis trinitária, que permita intuir Deus no mistério de sua kénosis. Pensar Deus kenóticamente é recolocar o sentido do mistério e da realidade à luz da fé no Deus que renuncia ao despotismo e, como escravo e servo assume a história dos homens. Este tema aponta para a permanente busca da teologia sistemática a novos paradigmas de compreensão e entendimento do Deus que se revela. Pensar Deus no mistério de sua kénosis é desconcertante, caem-se imagens, catequeses e "teologias" pré-estabelicidas. Brota-se a crise e por si crescimento, pois metodologicamente exige revolução no sentido normalmente confuso e limitado da compreensão do mistério. Um Deus kénotico é aquele que oculta sua face de glória e esplendor. Falar de um Deus-kenótico, que livremente escolhe participar da história dos homens, fazendo-se solidário a esses mesmos homens em suas dores e sofrimentos, assumindo como sua a própria dramaticidade da história humana, só é possível apofaticamente ${ }^{2}$.

2 Pensar Deus não imutável, mas fiel; não imóvel, mas como aquele que se encontra no meio do seu povo; não como impassivel e indiferente, mas cheio de compaixão e misericórdia para com suas criaturas; não como apático e que está sentado em seu trono vendo a dramaticidade dos seus filhos, mas como aquele que é simpático porque sente as dores e participa do drama dos seus filhos. 
Quando se pensa Deus apofaticamente se articula dialeticamente a teologia apofática e a catafática ${ }^{3}$, pois o não da primeira está necessariamente conexo a um sim da segunda. Neste sentido a kénosis ilumina a espiritualidade e a mística da realidade aonde o homem na fé experimenta Deus que se revela escondendo-se e que se esconde revelando-se. Pensar Deus apofaticamente é um momento dialético que significa a recepção mística da realidade ${ }^{4}$ onde o Transcendente se faz imanente numa dinamicidade do Ser de Deus que é infinito e sempre novo Ato de Amor Trinitário.

\section{A kénosis das Pessoas divinas em analogia a kénosis do Filho}

Falar em teologia de kénosis da Trindade supõe centrar-se em sua categoria cristológica. Não existem lugares bíblicos que testemunham esta figura da kénosis da Trindade. A pergunta é obvia: como é possível esta transposição? Considerando a Pessoa de Cristo em sua kénosis, é correto estender esta categoria as outras duas Pessoas da Trindade. É possível falar que o Pai e o Espírito Santo são kenóticos tal como o Filho em sua encarnação? A atribuição da categoria de kénosis só se refere biblicamente ao mistério do Verbo Encarnado, tal como se encontra nos mais antigos hinos cristológicos, inseridos por Paulo na carta aos filipenses. Kénosis significa o despojamento por amor, sair de si para buscar o outro, para aproximar-se do outro e para salvar o outro. Na kénosis do Filho, Deus revela-se como o Deus da história que assume como Sua a totalidade da história dos homens. Em Jesus, Deus se fez kenótico manifestando-se como o amante que de tal modo se aproximou do ser humano, tornando-se um ser humano. Portanto há que ser prudente quando se aplica de forma analógica as outras Pessoas da Trindade. Mas no momento em que se interpreta dinâmica e extensamente o evento Jesus Cristo como mistério de total condescendência e de forma correlativa sua encarnação a kénosis como síntese de doação que abraça toda a existência do Crucificado-Ressuscitado, a reflexão sobre a Trindade

\footnotetext{
3 A teologia apofática é em primeiro lugar teologia, senão ela se torna imperceptivelmente numa negação ateísta da teologia. Ela permanece associada à teologia catafática como correlativo necessário.

4 CODA, Piero. L'altro di Dio - rivelazione e kenosi in Sergej Bulgakov.Roma: Città Nuova; 1998 , p. 66.
} 
se vê também influenciada. Só podemos falar da kénosis da Trindade em analogia ${ }^{5}$ a kénosis do Filho.

\section{Deus é amor, uma definição da kénosis-pericorética}

Quando se fala do ser de Deus, de sua natureza e intimidade, refere-se ao que a teologia chama de Trindade imanente, essa por sua vez, só pode ser compreendida a partir da Trindade econômica ${ }^{6}$ tal como se manifesta na história na pessoa de Jesus Cristo, revelador do Pai, portador e doador do Espírito Santo. Definir que Deus é amor só nós é possível por revelação, Deus se revela tal como ele é, neste sentido a própria realidade do amor requer a compreensão de um movimento dinâmico e inventivo onde há quem se doa e quem recebe num movimento recíproco de Amor. A expressão joanina Deus é $a^{7}{ }^{7}$ não significa simplesmente que Amor é próprio de Deus, mas aponta que ele mesmo é Amor. Essa é uma definição não descritiva, mas ontológica, expressa o ser mesmo de Deus. O amor não é uma qualidade de Deus, mas sua substancialidade. O Amor exprime a essência do Espírito de Deus e a sua vida, neste sentido há de conceber-se a Santíssima Trindade como Espírito, da qual a vida é o Amor ${ }^{8}$.

Dentro deste caminho metodológico escolhido para elucidar a questão de Deus, tal como abordada até o momento, torna-se pertinente e necessário recorrer à estrutura teológica elaborada pelo teólogo S. Bulgakov ${ }^{9}$ para sistematizar os passos seguintes. Ao desdobrar o conceito Espírito de Deus, Bulgakov parte da idéia de uma relação dialética entre a hipóstasis e ousia no Seio da Santíssima Trindade. "Deus é Espírito e como tal tem uma consciência pessoal de si (a hipóstasis) e uma natureza (a ousia). Esta união indissolúvel da natureza e da hipóstasis é a vida da divindade em si

5 Compreender a kénosis das Pessoas divinas em analogia a kénosis do Filho requer metodologicamente ressaltar que a teologia apofática é companheira obrigatória da teologia analógica.

6 "A Trindade econômica é a Trindade imanente e vice e versa". Axioma do teólogo Karl Rahner, onde se afirma que a Trindade se revela tal como ela é em si mesma, sendo assim é na manifestação histórico-salvífica que se conhece Deus em sua natureza.

71 Jo4,8.16

8 CODA, Piero. L'agape come grazia e liberta, Città Nueva, Roma 1994

9 Sergej Bulgakov, considerado um dos grandes teólogos ortodoxo do século XX. 
mesma"10. Esta relação dialética entre a hipostasis e ousia é indestrutível, inalienável e inviolável. Sendo assim há de se definir que enquanto hipóstasis Deus é uma personalidade tri-hipostática, onde a unidade pessoal se descobre na realidade dos três centros hipostáticos. O ser hipostático divino se realiza em movimento como ato que se afirma trinitariamente no outro. Esta afirmação de si é o Amor. Um amor dinâmico e inventivo compreendido como doação, recepção e reciprocidade. Nesta dinamicidade a personalidade se realiza como fonte de amor que renuncia a si mesmo, extasiando-se no outro. Este é um amor pericorético, que compreendido nesta lógica pressupõe necessariamente uma vinculação estreita ao conceito de kénosis. Ousa-se teologicamente intuir e falar de uma kénosis-pericorética, tal como verificarse-á posteriormente.

Antes de definir-se o conceito e a idéia de kénosis-pericorética, é necessário elucidar outras definições, tal como o termo pericóresis para a inteligibilidade do ser e da natureza de Deus. Compreender a substancialidade de Deus como pericóresis significa debruçar-se sobre o mistério do que Ele é. Pericóresis designa sempre a coabitação recíproca das Pessoas divinas, é o repousar recíproco de duas Pessoas na outra, assim como uma dança de roda. No plano pericorético, não há na Trindade nenhuma primazia de uma pessoa sobre a outra, mas alteridade, repouso e movimento, saída de si em direção ao outro. Cada Pessoa é ela mesma porque está voltada para as outras, elas se movem, uma dentro das outras, como numa ciranda, enquanto uma está no meio as outras giram em torno dela. Na dinâmica pericorética as Pessoas divinas "disponibilizam o espaço convidativo para o movimento, na qual podem desdobrar a sua eterna vitalidade ${ }^{11}$ ". Nesta prospectiva é mister compreender o movimento, a dinamicidade e a alteridade da omousianidade das três hipóstasis divinas, na pericóresis que se dá via ao amor homológo.12

10 PIKAZA, Xavier. Enchiridion trinitatis - textos básicos sobre el Dios de los cristianos. Salamanca; secretariado Trinitario, 2005.

11 MOLTMANN, Jürgen. P.265

12 O teólogo Jürgen Moltmann mostra que a aplicação do conceito pericoresis tanto as duas naturezas na cristologia quanto às três Pessoas na doutrina da trindade mostra a fecundidade do conceito. Por meio dele, pode-se ligar sem misturar não só "os diferentes" da mesma espécie, mas também "o diferente" de uma espécie. As três Pessoas divinas formam a sua pericóresis por meio do amor homológo, a divindade e a humanidade associam-se no homem por força dp amor heterológo. MOLTMANN, J. experiências de reflexão teológica - caminhos e formas da teologia cristã. São Leopoldo: Unisinos; 2004. p.263 
Acima se abordou a possibilidade de intuir um movimento no Ser de Deus que seja correlativo a kénosis e a pericóresis. Mas como pensar esta relação? O ponto de partida é a definição que Deus é amor, e sendo amor, manifesta-se tal como é. Se este é um ponto comum na compreensão da teologia da Trindade, sabe-se que alguns teólogos avançaram em suas reflexões contemplando na Trindade imanente a forma radical do amor que se tem manifestado na economia da salvação. Apriori e mister resgatar o pensamento do teólogo ortodoxo Bulgakov, este faz a seguinte pergunta: $O$ que é realmente o amor? Ao responder sintetiza-o em dois axiomas interligados. Não há amor sem sacrifício; e nem amor sem glória e sem beatitude. Segundo Bulgakov a glória é superior ao sacrifício porque ela vem por ultimo, pois de certo modo a glória é resultado do sacrifício. "Em síntese o amor se mostra como antinomia concreta: sacrifício e descoberta de si mesmo graças ao sacrifício. Uma vez trágico o amor é ao mesmo tempo superação da tragédia: é próprio nisto que consiste a força do amor ${ }^{13}$ ".

Ao apresentar esta idéia de amor onde estão correlacionados sacrifício e glória, permite intuir que em Deus há um sacrifício eterno e original que não pode ser compreendido como dor e imperfeição, mas somente como movimento de doar-se, de perder-se no outro para que o outro seja o outro e para ser no outro. Como já refletido anteriormente o amor não é uma qualidade de Deus, mas sua substancialidade, o amor é relação, reciprocidade de quem se doa e se recebe. É o recíproco expropriar-se por amor que faz as Pessoas divinas serem o que são: doação, recepção e reciprocidade, o que são em si mesmas constitui a vida intratrinitária.

Se, se compreende dentro deste princípio teológico, torna-se relevante afirmar que kénosis no sentido moderno do termo significa "a pessoa despojar-se por amor do que lhe é próprio, dar-se totalmente para fazer-se um com os outros, para viver o outro, para permitir que o outro se realize e, desse modo, colocar as condições para ser plenamente ele próprio ${ }^{14 "}$. Dentro desta lógica teológica, intuir uma kénosis-pericorética é debruçar-se diante do ritmo amoroso do ser de Deus, onde doação e recepção são eternamente divinos. Ao doar-se o Pai se doa inteiramente, não retendo nada para si doa

${ }^{13}$ CODA, Piero. Op. cit. p. 101.

${ }^{14}$ CAMBÓN, Enrique. Assim na terra como na Trindade. O que significam as relações trinitárias na vida em sociedade? São Paulo: Cidade Nova, 2000, p.29. 
tudo de si. É nesta compreensão da geração do Filho que tudo recebe do Pai que se compreende a kénosis-pericorética.

O Pai se esvazia, dá tudo, transmitindo ao Filho e condividindo com o Filho no Espírito tudo o que é. Neste doar-se totalmente ao outro, há sempre uma relação, onde cada Pessoa divina está nas outras como ela mesma totalmente em si e nas outras. Sendo assim a diferença das Pessoas divinas é a condição e a possibilidade de existir amor e intercambio. Ser um-com-o-outro e um-para-o-outro. O que constitui a paternidade em Deus é o amor-doação, concomitantemente a filiação é o amor-recepção e a expiração é o amor-reciprocidade. A partir deste principio compreende-se o pensamento de Bulgakov: "a paternidade é a forma do amor em que o amante se esvazia de si mesmo, não em si, mas fora de si, no outro, para da-lhe o seu próprio eu aquele outro eu que também ele identifica consigo por manifestar o próprio eu na geração espiritual, no Filho, que é a imagem viva do Pail". Se a paternidade é a forma em que o amante se esvazia no amado pelo amor, também o amado como resposta se esvazia no amante pelo amor. Nisto consiste a Filiação, pois o Filho no Espírito se esvazia em nome do Pai. "A condição de Filho é já uma eterna kénosis"16.

Se o amante se esvazia no amado e o amado no amante, também o amor que os une e os diferencia se esvazia de maneira muito profunda. $\mathrm{O}$ recíproco amor do Amante e do Amado é a glória deste amor que compõe a auto-revelação da Divindade na sua natureza, não só em Verdade, mas também em Beleza ${ }^{17}$. Esta reciprocidade de amor é a especificidade da revelação kenótica do Espírito Santo como amor. O Espírito é o amor que reúne em si todo processo de amor: o sacrifício e a glória. Ele não revela a sua hipóstasis como acontece com o Pai e o Filho, mas perscruta cada coisa, também a profundidade e a intimidade de Deus ${ }^{18}$. O Espírito não existe por si, ele é tudo nos outros, o seu ser é como um não-ser por amor e exatamente por isso é Espírito Santo. Ele é na Trindade mistério de comunhão na diversidade um doar-se a si mesmo. É mistério de extroversão e alteridade é kénosis mesmo da Trindade.

\footnotetext{
${ }^{15}$ BULGAKOV, Sergej. L'agnelo di Dio, il mistero del Verbo incarnato. Roma: Città Nuova, 1990, p. 154.

16 Ibid.155.

17 Ibid. 156.

${ }^{18}$ Cf. 1 Cor 2,10
} 
A kénosis da Trindade

Nesta kénosis trinitária contempla-se o mistério do recíproco expropriar-se por amor que fazem as Pessoas divinas serem o que são: doação e realização, pois dar a vida aos outros é realizar a própria identidade. Debruçado sob este ritmo de amor que há em Deus, intui-se que tudo é kénosis por isso pericóresis. Assim o Pai, o Filho e o Espírito Santo, estão sempre na rítmica do amor sempre em comunhão pericorética. Cada Pessoa saindo de si para os outras, obtém simultaneamente sua identidade a partir das outras. Neste movimento de saída e de busca há sempre o encontrar-se, então se pode dizer que há um "não originário", ou seja, um "não por amor", esse "não" deve ser compreendido como "não-ser-em-si-mesmo", senão "ser-no-outro e com-o-outro". Esse "não" significa a infinita afirmação de si e concomitantemente a afirmação dos outros. É um "não na afirmação", que abre espaço na relação, na alteridade e na comunhão. Um "não na afirmação" pericorética, onde cada Pessoa é ela mesma a medida em que se doa.

\section{A kénosis do Espírito Santo como kénosis da Trindade}

Metodologicamente pode-se dizer no sentido moderno do termo, que compreender o conceito de kénosis é redescobrir novos caminhos que ajudam a reinterpretar o ser próprio de Deus enquanto onipotência do amor sem medida. Kénosis aqui é entendida como expressão da essência da Trindade como mistério de superabundância de doação e serviço para a comunhão. Neste sentido kénosis e pericoresis são dimensões constitutivas do ser de Deus. A unidade pericorética é constituída pela kénosis recíproca.

Mas ao elucidar especificamente a kénosis do Espírito Santo como kénosis da Trindade é preciso resgatar a categoria de kénosis de Cristo, como dito anteriormente, para distinguir a kénosis do Espírito, pois a kénosis do Filho vem determinada pela encarnação do Verbo em sua condição divino-humano, o mesmo não se pode dizer ao Espírito Santo, este não se encarna, não tem uma carne própria para agir, age na carne na fragilidade dos homens. A kénosis do Espírito é mais profunda que a kénosis do Filho, embora esta não esteja determinada por uma nova união hipostática em função do modelo do Verbo encarnado.

A kénosis do Espírito traduz de maneira veemente, criativa e nova a compreensão do que é o ser próprio do Espírito Santo no Seio da Trindade e na Criação. Neste sentido é mister destacar a diferença entre a kénosis 
do Filho e a do Espírito Santo, esta distinção tem sido elaborada sistematicamente por Bulgakov. Se o Filho ao encarna-se abandona o seio de Deus, pois sua kénosis é marcada pela humanização de Deus, o Espírito Santo ao contrário, ao fazer-se kenótico na historia da salvação não abandona o seio e Deus e nem se despoja da divindade, sua kénosis não está determinada pela humanização de Deus, mas a divinização do homem que se dá pela comunicação divina ${ }^{19}$. Se na kénosis do Filho, Deus faz ser dele a história dos homens, na kénosis do Espírito Santo, Ele faz ser dos homens o que Ihe é próprio, ou seja, manifesta a natureza comum da Trindade, deixando que a sua Pessoa seja dissimulada sob a divindade. O Espírito permanece não revelado, escondido pelo dom que ele mesmo comunica, mas que foi acolhido e apropriado à pessoa humana ${ }^{20}$. Pela kénosis do Espírito Santo se compreende que Deus ama loucamente o ser humano, por isso não se cansa de buscá-lo, mesmo por caminhos e meios escandalosos, tal como este que se dá de maneira kenótica onde se inclina, se abaixa e se lança a buscar o ser humano adaptando se a ele e adaptando-o a $\mathrm{Si}$.

A tradição ortodoxa tem mostrado a kénosis como amante abandono de si, transcendendo a natureza para realizar a pessoa. O Espírito Santo que se esconde e se manifesta realiza, sem confusão e nem separação a união dos seres humanos com a Trindade e vice e versa ${ }^{21}$.

$\mathrm{Na}$ Trindade imanente, o Espírito Santo é antes de tudo o amor hipostático e kenótico que se manifesta escondendo-se na relação diádica entre o Pai e o Filho. É como se no interior de sua processão se perdera a si mesma. Assim afirma Bulgakov: "O caráter da Terceira Hipóstasis como amor se expressa neste entre com inserção em si mesma da hipóstasis amante-amado (...) Na terceira Hipóstasis, a kénosis se expressa em um esvaziamento da personalidade (...) que se faz transparência ante os outros. Por isso tem adquirido para si a perfeição da vida divina: a glória"22.

A especificidade do Espírito Santo é a sua revelação kenótica como Amor, pois, o Espírito que é amor renuncia em si todo processo do amor na própria sacrificialidade do amor. Esta renuncia consiste no seu ocultamento

\footnotetext{
${ }^{19}$ Sergej Bulgakov, Il Paraclito. Bologna: EDB, 1987, 582-583

20 V. Lossky. La teologia mística della Chiesa d"Oriente. Bologna: II Mulino, 1967, 160s.

21 Ibidem 160-165

22 Sergej Bulgakov. Op. Cit. p. 347.
} 
hipostático. O Espírito diferente do Pai e do Filho não revela a sua hipóstasis e nem a si mesmo, mas em sua kénosis se compõe o ápice do amor. "No amor que é a Santíssima Trindade, a terceira hipóstasis é amor mesmo, que realiza em si, hipostaticamente, toda a plenitude do amor ${ }^{23}$ ".

A não-revelabilidade hipostática do Espírito Santo é um fato contingente que concerne à história da salvação, pois segundo Bulgakov: "o homem só conhece o amor como um estado ou uma propriedade da hipóstasis, mas não como hipóstasis em si. Nesta transcendência do amor, princípio hipostático, se exprime o mistério particular da terceira hipóstasis, a sua inacessibilidade por nós, a sua não-revelabilidade"24.

\section{O mistério da Trindade manifestado no hoje da salvação}

Partindo do que foi refletido até o momento, pode-se dizer que a kénosis é a dimensão fundamental do ser de Deus, pois ao fazer-se homem a Trindade imanente se fez econômica. Isto porque a comunhão das Pessoas divinas não está cerrada em si mesma, ao contrário está aberta para fora de si mesma: para toda humanidade e para toda a criação. Da eternidade o Pai envia o Filho e o Espírito Santo, eles são comunicados aos seres humanos, como misericórdia e amor. A vida humana é o lugar da imanência do Filho e do Espírito Santo, e pelo fato de estarem imanentemente na humanidade e na história é que se atribui a eles o caráter de enviados.

Se a teologia tradicional ressalta a teologia das missões somente em relação a encarnação de Jesus e a vinda do Espírito Santo prometido e dado por ele em virtude da sua obra salvífica. A teologia contemporânea tem trazido uma contribuição relevante aquela que afirma que o Filho e o Espírito Santo não estão atuando na criação somente a partir da encarnação, mas ao contrário, a ação do Filho e do Espírito Santo pertence a realização da criação como tal. Deus desde o ato criador está presente na história trinitariamente. O Filho e o Espírito Santo no ato criador já estão enviados.

Porque o Filho e o Espírito Santo agem kenóticamente na história e na vida dos seres humanos, conclui-se que a pessoa humana é verdadeiro

\footnotetext{
23 Ibidem, p. 122.

24 Ibidem, pp. 288-289.
} 
templo de Deus, pois, Deus quer habitar livremente na profundidade do seu coração. Quando o ser humano se abre acolhendo o supremo amor e se une nesta relação-comunhão com o próprio Deus, porque é ontologicamente pericóresis, ou seja, relação e comunhão, torna-se um com Ele e então, mas humano e cabal, atingindo sua exaustiva hominização e sua divinização.

Se o Espírito Santo é na intimidade de Deus, no interior da Trindade relação e reciprocidade, acolhendo e deixando espaço sem menosprezar a si mesmo, então na base da economia salvífica ele é ocultamente na manifestação é o "entre-pessoas" que une a diversidade na comunhão. É a possibilidade da extraordinária pericóresis entre Deus e o mundo. $\mathrm{O}$ que o Espírito realiza dentro da Trindade unindo o amor paterno ao amor filial como unidade-comunhão da paternidade e filiação, na relação com os homens, o extasis parterno de Deus para o homem passa a converter-se em extasis filial do homem para Deus. O homem ama ao Pai graças ao que Deus mesmo tem derramado em seu coração: O Espírito Santo ${ }^{25}$.

É próprio da kénosis do Espírito fazer ser do homem o que é próprio de Deus, pois sua Pessoa fica como que dissimulada sob a divindade, como exorta o apostolo Paulo: "só no Espírito podemos clamar Abba-Pai26" Este grito no Espírito se faz presente agora no homem, porque o Espírito Santo mergulha em sua kénosis, se abaixando, se escondendo, para que o extasis do homem o seja próprio desde a totalidade da sua liberdade, então o grito Abba-Pai, tornou-se verdadeiramente seu grito, porque também o amor ao Pai, tornou-se seu amor. O amor com que amas é o amor a quem amas.

\section{A criação como kénosis do amor trinitário}

O grande teólogo Jürgen Moltmann tem afirmado que a obra da criação, ao contrário do pensamento agostiniano que a atribui somente ao Pai, é obra do amor do Pai, e com isso atribuída a toda a Trindade ${ }^{27}$ No Filho, pensamento eterno do Pai se realiza o ato criador $^{28}$. O Pai se volta eternamente

\footnotetext{
${ }^{25}$ Cf. Rm 5,5

${ }^{26}$ Cf. Rm 8,15

${ }^{27}$ MOLTMANN Jürgen. Trindade e Reino de Deus - Uma contribuição para a teologia. Petrópolis: Vozes; 2000, p.123.

${ }^{28}$ Cf. Jo1; Ef 1; Cl 1,15s
} 
para o Filho, cria pensando nele. O Pai em Cristo tudo modela e tudo faz. No ato da criação Deus repete de maneira análoga, o que tem espaço em Deus mesmo desde toda a eternidade.

As Pessoas divinas, a partir de suas propriedades mais intimas, constituem o seu ser ao deixar espaço para os outros. Deixar espaço pertence à essência da Trindade, neste sentido na realização da vida intra-trintária já existe um espaço para a criação. Ao criar Deus se retrai, dando espaço para que a criação seja. "Deus retira-se de si mesmo para si mesmo para tornar possível a criação. A sua atividade criadora para fora é precedida por esta humilde auto-restrição divina" ${ }^{29 "}$

Esse movimento criador de Deus de retirar-se de si para si mesmo permite compreender que é na idéia trinitária de Deus, onde cada Pessoa dá espaço às outras duas que a autonomia da criação é garantida. É próprio da essência de Deus dar-lugar ao outro, assim como na alteridade das Pessoas divinas, também ao totalmente outro da criação. Esse movimento de retirar-se, é entendido também como um movimento uterino de Deus, como uma contração visceral, assim como uma mãe que gera para dentro de si e depois dá a luz ao que foi gerado em seu ser. Esta imagem que perpassa permite intuir que Deus é a mãe que dá a vida dando amor.

A mística judaica apresenta a partir da cabala a idéia do zimzum de Deus, procurando solucionar o problema da idéia da auto-limitação de Deus na criação. Somente ali onde Deus se retrai de si em si mesmo, pode surgir algo que não seja essência divina e ser divino. A mística e a teologia cristã, resgatando este princípio judaico formulam a idéia da kénosis divina, compreendendo o zimzum trinitário como recepção, aceitação total e participação no amor de Deus.

A criação como kénosis do amor trinitário tem seu paradigma de ser e sua forma de existir na vida intima de Deus, no mistério da Trindade onde as Pessoas divinas se reconhecem reciprocamente na alteridade, onde cada uma está nas outras dando e recebendo concomitantemente. Como afirma o teólogo Gibert Greshake: "Deus reconhece a criação como o outro de si

${ }^{29}$ MOLTMANN Jürgen. Deus na criação. Doutrina ecológica da criação. Petrópolis: Vozes; 1993, p. 138. 
mesmo, é capaz de estar em si mesmo na alteridade da criação e a introduz desse modo no intercambio de sua própria vida divina ${ }^{30 "}$.

Compreender a criação como kénosis do amor trinitário, é, impreterivelmente necessário se perguntar: qual é o espaço trinitário da criação? Se há um "não originário", que é um "não na afirmação", que abre espaço na relação, na alteridade e na comunhão, a criação enquanto o totalmente outro de Deus, só pode ter seu lugar e seu espaço Naquele que é o eternamente Amado, ou seja, no Filho, a eterna recepção do amor filial que corresponde eternamente ao dom paterno.

O lugar trinitário da criação está no Filho, pois como ele, a criação embora em sua condição de finitude esteja colocada na condição de interlocução do Filho frente ao Pai. Está relacionada de forma permanente com o Pai e com o Filho através do Espírito Santo que a abrindo e transformando-a desde dentro a conduz para a vida divina da Trindade ${ }^{31}$. A criação tem seu espaço na comunhão pericorética de Deus e está chamada como o "outro" de Deus, a participar, por graça da esplendida e extraordinária pericóresis, ou seja, da recíproca inabitação de um no outro, que por si exigi e exprime a recíproca alteridade e distinção.

\section{A kénosis trinitária manifestada no evento pascal de Cristo}

Compreendendo tudo que foi dito até o momento, pode-se dizer que a dinâmica da kénosis da Trindade que é o segredo guardado no intimo de Deus, é manifestada na história da salvação no evento pascal de Cristo, de modo singular na experiência do Jesus de Nazaré, o Filho amado do Pai que experimenta enquanto Filho a separabilidade da inseparabilidade.

O Filho enquanto homem-Deus mergulha nas profundezas do desespero humano frente à solidão e abandono. Se faz só com a solidão humana, é considerado por Deus como sendo o próprio pecado ${ }^{32}$. O seu grito de abandono expressa a própria experiência de separação, pois aquele que o acompanhou em toda a sua vida, agora é reduzido a pura potencialidade. $\mathrm{O}$

\footnotetext{
30 El Dios Uno y Trino. Uma teologia de la Trinidad. Barcelona: Heder; 1997, p. 286.

31 Dominum et Vivificantem, de João Paulo II, n 59

${ }^{32}$ Cf 2 Cor 5,21
} 
repousar do Espírito que é inseparável e inalienável foge a sua consciência. É como se o Espírito o abandonasse, ele está desprovido na sua condição humana, daquele que sempre o acompanhou. Está desprovido da própria experiência daquele amor que sempre o motivou.

O Filho mergulha numa certa interrupção da perceptíbilidade da manifestação do amor que sempre o impulsionou. O amor do Pai parece esconder-se em si mesmo, não chegando mais ao Filho, por isso mergulha nesta percepção de separação e afastamento do Pai. Sua cruz torna-se o próprio drama da solidão kenótica sacrifical. O Filho está só na sua agonia, mas também o Pai experimenta esta solidão, por que de certo modo perde o Filho. O abandono experimentado pelo Filho por parte do Pai deve ser compreendido em analogia do afastamento recíproco do Pai e do Filho. "O abandono do Filho da parte do Pai só pode ser entendido como participação do Pai na agonia do Filho, ao sofrimento do seu amor sacrifical, da renuncia de si'33.

Se o abandono experimentado pelo Filho é a participação do Pai em sua agonia, então, não se trata propriamente de uma separação, mas de unidade na agonia onde cada Pessoa divina experimenta de modo singular a intensidade desta dor e deste abandono. Nesta perspectiva afirma o teólogo Bruno Forte: "a trindade revela-se na kénosis, isto é, no sofrimento de amor. Deus é um Deus que sofre". ${ }^{44}$ Sofre, porque ama, porque é um Deus que se revela apaixonado pelo ser humano. Sofre porque o ser humano sofre. Neste sentido o abandono experimentado por Jesus é revelatório, nele está o mistério kenótico da Trindade, o da dor de amor que habita em Deus. O Pai e o Espírito Santo estão mergulhados nesta comum agonia em que sofre o Filho, e este está em comum agonia com o sofrimento humano. Esta co-agonia trinitária é a agonia do Filho e de todos os homens.

A Trindade revela-se também na ressurreição. "Ressurreição da Trindade" como expressa Bruno Forte, por meio dela compreende-se que existe a morte em Deus, como um conceito agápico. Deus sofre porque seus filhos sofrem, mas ressurge para a vida ${ }^{35}$.

\footnotetext{
${ }^{33}$ CODA, Piero. Op. Cit. p. 176.

${ }^{34}$ FORTE, Bruno. Envolvidos no mistério da transfiguração - um itinerário para o jubileu. Coimbra: Gráfica Coimbra; 1996, p. 73.

35 Ibidem. p 76
} 
Se o Espírito se esconde kenóticamente na experiência de abandono, isto se dá, porque o amor do Filho ao Pai e do Pai ao Filho se compraz na glória da ressurreição. O Pai ressuscita o Filho no Espírito Santo ${ }^{36}$. Ele o ressuscita com uma ação paternal: amando-o, ou seja, o Pai o ressuscita pela potência vivificando do seu amor que é o Espírito Santo que transforma e faz de Jesus Crucificado, que vivera em situação kenótica ${ }^{37}$, o vivente e o vivificante. Cristo ressuscitado está permeado do Espírito divino é totalmente transformado em realidade pneumática.

\section{O sofrimento de Deus como kénosis do Amor}

No mistério da paixão, morte e ressurreição de Jesus, o homem descobre o verdadeiro rosto de Deus-onipotente. Na morte de cruz, Deus se revela como onipotente no amor. Ele vai até a ultima conseqüência desse amor pelos homens, pois o fato do Pai não ter poupado o próprio Filho, expressa que nada, literalmente nada pode impedir a eloqüência do amor-onipotente de Deus-Pai pelos homens. A onipotência deste amor, não implica nenhuma força totalitária, irracional ou arbitrária. Esta deve ser entendida à luz da paternidade de Deus. "A onipotência divina se realiza engendrando o Filho em plenitude, no supremos sacrifício do calvário e na aurora da manhã da Páscoa" ${ }^{38}$. Sabe-se por revelação que o máximo da onipotência de Deus se expressa na ressurreição de Jesus como efeito do amor paterno que se derrama como doação infinita graças ao Espírito Santo que se kenotiza na história de Jesus e na história de cada homem de todos os tempos e lugares.

O Espírito resplandece na história dos homens, a regeneração da nova vida no único e mesmo mistério pascal. O Espírito Santo em sua kénosis, faz com que cada homem torna-se contemporâneo dos acontecimentos de Cristo. É como se a vida humana estivesse envolvida numa grande liturgia onde o torna-se contemporâneo de um acontecimento passado só é possível

\footnotetext{
${ }^{36}$ Cf $\mathrm{Rm} 8,11$

37 O Filho se esvazia de si, com sua kénosis se faz pequeno. Pois sendo Deus-homem, se manifesta somente como homem. Na hora de sua morte, se rende indefeso diante dela, se faz sujeito, acolhe a própria mortalidade.

${ }^{38}$ CIOLA, Nicola. Cristología y Trinidad: Salamanca; Secretariado Trinitário, 2005, p.69
} 
via uma ação de poder divino que dissimulado na história real resplandece a irrupção do Espírito Santo e faz presente o evento pascal de Cristo.

Se o poder divino se faz dissimulado na história dos homens, compreende-se que o ícone da onipotência de Deus, não pode ser outro, senão aquele que brota do amor incriado de Deus. Aquele que desconcerta a lógica humana da prepotência e da arrogância, da hegemonia, da força e do poder. O ícone kenótico da pobreza é por sua vez é ícone da riqueza do Deus cristão, que se revela em atitude de amor e misericórdia, atitude de ternura e compaixão. Não há onipotência do amor sem a oni-debilidade deste mesmo amor. O amor é débil, frágil e vulnerável no mundo, pois só assim torna-se para homem, esperança e força, certeza e solidariedade. "O paradoxo do Deus cristão é o fato de ser onipotente porque é débil, humilde e imolado. A onipotência é a capacidade infinita do dom de si ao outro"39.

Graças a Jesus de Nazaré, o fato histórico, pela sua vida, seu comportamento diante de Deus e dos homens, assiste-se uma nova maneira de conceber a onipotência de Deus, tal como aquela que se contempla de maneira dissimulada na figura do bom pastor que sente compaixão dos que sofrem e dá a vida por suas ovelhas. Jesus o bom pastor une de maneira singular sua paixão pelo Pai e sua compaixão para com os pobres. Sua vida tem um significado universal para toda a humanidade: ser-para-os-outros. É o caráter de diakonia. Na sua práxis a onipotência de Deus se apresenta entranhada na história daqueles que sofrem, e de modo particular na paixão, na dor e no sofrimento dos pobres, dos considerados não-humanos e que substancialmente são filhos de Deus. Em Jesus, Deus se faz fraco com os fracos, pobre com os pobres, vulnerável com os vulneráveis, débil com os debilitados.

A compaixão do bom pastor é à força de Deus dissimulada nas atitudes e nas palavras de Jesus, não aceita por um sistema detentor de um poder e de uma força hegemônica e avassaladora que gera assustadoramente novos campos de concentrações e de pobrezas. Auschwitz metáfora da exclusão é hoje, lá onde o Deus onipotente está enforcado com os enforcados, morto com os mortos, pobre com os pobres, vitimado com todas as vítimas, sofrendo com todos os sofredores. A vida dos pobres e dos excluídos, dos considerados não-humanos, dos injustiçados torna-se cada vez mais um

39 Ibidem p. 72 
lugar teológico, nela e a partir dela cada homem deve lançar o seu grito de indignação e o teólogo compreendê-la como lugar hermenêutico. Ao perguntar-se onde está Deus, frente às atrocidades, violências e pobrezas estigmatizadas, saberá que Deus está ali, kenoticamente apresentado, revelando-se oculto e escondido dentro desta impotência revelatória, na qual ele já não parece nem mesmo ser Deus e nem mesmo homem, manifestando assim, a sua onipotência de Amor. Descobrir um Deus kenótico é experimentá-lo na história, não como um mago ou curandeiro, capaz de determinar a toque de magia o desdobramento desta história marcada pela experiência dolorosa do pecado, do mal e da morte, mas descobri-lo como um Deus apaixonado que ama loucamente o ser humano, por isso se doa eloquentemente no oferecimento do seu Filho Unigênito. Esse amor louco de Deus não destrói mecanicamente o mal e a morte, ao contrário, ele os assume, pois o Deus Trindade através da morte de Jesus tem vencido a morte através da morte.

Perguntar por Deus frente às atrocidades cometidas por lideres e estruturas ditatórias e de modo preciso, frente aos sofrimentos experimentados, significa para o cristão e de modo preciso para o teólogo, comprometer-se com as vítimas e com seus sofrimentos, assumi-los e sofrê-los com os outros através da ação de Jesus ressuscitado e do seu Espírito derramado sobre os crentes. A ação kenótica do Espírito Santo é a seguridade de que o Filho segue vivo e continua a sua missão de edificar o Reino de Deus, na ação profética e kenótica da sua Igreja.

Mas como compreender o sofrimento de Deus? Metodologicamente é preciso primeiramente resgatar a correlação existente entre amor e sofrimento, desde a compreensão da dimensão pericorética de Deus. Se Deus é Amor na unidade e distinção de pessoas, sua natureza supõe uma certa auto-limitação, onde cada Pessoa se retrai deixando ser afetada pelas outras, fazendo-se vulnerável no amor. Nesta "vulnerabilidade pericorética" o amor e o sofrimento se correspondem. Assim afirma o teólogo Walter Kasper: "O sofrimento do amor não é uma afeição passiva, senão um deixar-se afetar ativo. Sendo Deus Amor, pode padecer e manifestar assim sua divindade"40.

Outro ponto pertinente para tal compreensão é retomar o conceito de pessoa resgatado por Ricardo de São Vitor, para se buscar a inteligibilidade

${ }^{40}$ KASPER, Walter. El Dios de Jesucristo. Salamanca; Verdad e Imagen; 1998, p. 228. 
do acontecimento histórico da paixão e morte de Jesus, o Filho de Deus, donde procede o Espírito de amor e de entrega, que conforta e se solidariza com todos os homens desamparados e sofredores. Dentro desta compreensão a Trindade já não é uma mera especulação sobre o mistério de um Deus sobre os homens, como afirma o teólogo Moltmann, ela constitui a expressão mais concisa da história da paixão de Cristo. A história de Cristo é a história de Deus e esta por sua vez, é a história entre o Pai, o Filho e o Espírito Santo.

Se Deus Trindade assume a história do Filho, é porque assume a história dos homens na sua paixão e na sua dor. Isto significa que o ser de Deus é histórico e existe na história concreta de todos os homens e de todas as épocas. É na história dos homens que se configura o sofrimento de Jesus experimentado no abandono do Pai. Ao se fazer ausente, o Pai sofre a morte do Filho na dor da eloqüência do seu amor. Na morte experimentada pelo Filho, o Pai a sofre em dor de amor Porque Ele é onipotente no amor, então ele está lá, junto com os seus filhos que sofrem e morrem. Compreende-se isto a luz da Trindade, pois o Pai sofre e participa dessa morte por amor ao Filho e aos seus filhos. Seu sofrimento por amor não está em contradição com a sua perfeição e a sua imutabilidade. Ao sofrer porque seus filhos sofrem, Deus compartilha deste pão com os homens ${ }^{41}$. Então, o rosto do sofrimento é o amor misericordioso e excessivo que na essência se expressa como doação.

É um Pai que padece e se imola, não a modo humano, por deficiência no ser, mas de modo divino, por amor, de amor e em seu amor. Cabe aqui compreender que o Espírito Santo em sua kénosis revela ao ser humano que o amor trinitário é concomitantemente extático e kenótico, pois ele une na dor, o Filho com o Pai e os homens com a Trindade. Sendo assim intuise que tudo o que o Filho tem experimentado na carne humana, o Pai tem

\footnotetext{
${ }^{41}$ Afirmação do grande teólogo ortodoxo Paul Evdokimov: "A onipotência do manikós éros, do amor louco de Deus não destrói mecanicamente o mal e a morte, senão que os assume: através da morte tem vencido a morte. Sua luz nana da verdade crucificada e ressuscitada. Sendo assim frente ao sofrimento dos inocentes, dos acontecimentos absurdos da vida, é necessário aplicar a Deus a noção paradoxa da debilidade invencível. A única resposta adequada é afirmar que Deus é débil e que não pode outra coisa que sofrer conosco; o sofrimento é o pão que Deus compartilha com o homem. Certamente não é o Deus débil em sua onipotência formal, senão em seu amor que renuncia livremente a onipotência. L' amore folle di Dio. Apud CIOLA, Nicola. Cristología y Trinidad. Salamanca: Secretariado trinitário;2005, p. 72.
} 
vivido e interpretado desde a eternidade ${ }^{42} \mathrm{~A}$ onipotência do amor de Deus é a revelação do seu ser Trindade como continua kénosis-pericorética de doação, recepção e reciprocidade, que supera a impotência do sofrimento. Em Jesus Cristo, o sofrimento é transformado em esperança desde dentro, a ultima palavra não pode ser a kénosis e o sofrimento, mas a exaltação e a transfiguração. Então falar de um Deus-kenótico, que livremente escolhe participar da história dos homens, fazendo-se pobre com os pobres, solidário com os injustiçados e com os que sofrem, desfigurado com os desfigurados, sem fisionomia nem de Deus e nem de homem, assumindo desde dentro os dramas e as tramas da vida humana, só é possível apofaticamente.

\section{CONCLUSÃO}

Ao considerar a kénosis trinitária como objeto material e a teologia da kénosis como objeto formal da doutrina da Trindade, compreende-se que a Trindade não pode ser concebida como uma especulação sobre os mistérios de um Deus distante, inatingível e inalcançável. Ao contrário é um convite a debruçar-se sobre o mistério kenótico de Deus-Trino que se nos revela na história. A história é o lugar iminente da presença kenótica de Deus. É na história que a Trindade imanente se tem tornado definitivamente e absolutamente Trindade econômica, fazendo-se solidária ao mundo dos pobres e excluídos.

O Filho em sua kénosis se faz verdadeiramente homem, presença encarnada, companheiro de caminho e de destino com o homem. Ama profundamente o Pai e os homens num mesmo amor, sua paixão pelo Pai é sua compaixão para com os homens. Em sua kénosis, Deus se faz acessível aos homens com rosto humano, tornando a imagem visível do Deus invisível.

O Espírito Santo age kenóticamente entrelaçado no tecido da criação e da história. Em sua kénosis, Deus não age somente como companheiro, ou parceiro de caminhada do homem, mas inabitando no coração dos justos. Deus na kénosis do Espírito, porque o derrama nos corações humanos ${ }^{43}$, habita-os desde dentro, por isso o Espírito torna-se na relação Deus e homem, intimidade e comunhão.

\footnotetext{
42 Ibidem p. 74

${ }^{43}$ Cf. $\mathrm{Rm} 5,5$
} 
O Pai, como mistério originante de tudo, pois é doação pura e origem de toda a Trindade, engendrando o Filho se entrega totalmente a Ele no Espírito, não retém nada para si, doa tudo, oferece tudo, faz-se de certo modo "não ser por amor", e por isso é Pai. Ao entregar o Filho e o Espírito Santo aos homens, repede de maneira análoga o que constitui o ser de Deus. Dando o Filho e o Espírito, o Pai se doa por inteiro, se entrega, se oferece, envolvendo deste modo, todo e qualquer homem no mesmo amor com que ama seu Filho Unigênito.

Em Jesus e no Espírito, o Pai tem se relacionado com seus filhos de maneira nova e desconcertante, não mais um Deus que age como um pai, ao modelo do Antigo Testamento, ao contrário se revela e se manifesta sendo Abba-Pai, assumindo a figura daquele que se aniquila, que se abaixa para aproximar-se e caminhar lado a lado com os seus filhos.

A onipotência de Deus é capaz de realizar-se como impotência, debilidade e vulnerabilidade do poder do amor. Em sua kénosis trinitária, torna misteriosamente a onipotência e a impotência como que modalidades da única realidade divina: amor perfeito, que livremente quer introduzir a criação na vida trinitária de Deus e criar assim a extraordinária pericóresis entre Deus e o mundo. "Deus em todas as coisas - todas as coisas em Deus ${ }^{44 "}$.

\section{BIBLIOGRAFIA}

\section{Fonte}

BIBLIA SAGRADA. Tradução Ecumênica da Bíblia. São Paulo: Paulinas/Loyola, 1994.

\section{Magistério}

JOÃO PAULO II, SS. Carta Encíclica Dominum et vivificatem: O Espírito Santo na vida da Igreja e do Mundo. São Paulo: Paulinas, 1998.

\section{Autores}

BOFF, Leonardo. A Trindade, a sociedade e a libertação. Petrópolis: Vozes, 1986.

BULGAKOV, Sergej. L'agnelo di Dio, il mistero del verbo incarnato. Roma: Città Nuova, 1990.

Il Paraclito. Bolongna: EDB, 1987.

${ }^{44}$ CF. 1 Cor 15,28

62 
CAMBÓN, Enrique. Assim na terra como na Trindade. O que significam as relações trinitárias na vida em sociedade? São Paulo: Cidade Nova, 2000.

CIOLA, Nicola. Cristologia y Trinidad. Salamanca: Secretariado Trinitário, 2005.

CODA, Piero. L'altro di Dio, rivelazione e kenosi in Sergej Bulgakov, Roma; Città Nuova, 2005.

FORTE. Bruno. Envolvidos no mistério da transfiguração. Um itinerário para o jubileu. Coimbra: Gráfica Coimbra, 1996.

L'agape come grazia e liberta. Città Nuova: Roma, 1994.

GRESHAKE, Gilbert. El Dios Uno y Trino. Uma teologia de la Trindad. Barcelona: Heder, 1997.

KASPER, Walter. El Dios de Jesucristo. Salamanca: Verdad e Imagen, 1998.

LOSSKY, V. La teologia mística della chiesa d'Oriente. Bologna: II Mulino, 1967.

MOLTMANN, Jürgen. Experiência de reflexão teológica. Caminhos e formas da teologia crista. São Leopoldo: Unisinos, 2004

Trindade e Reino de Deus. Uma contribuição para a teologia. Petrópolis: Vozes, 2000.

Deus na criação. Doutrina ecológica da criação. Petrópolis, 1993.

PIKAZA, Xavier. Enchiridion trinitatis. Textos básicos sobre el Dios de los cristianos. Salamanca: secretariado Trinitário, 2005.

Pe. Donizete José Xavier

Licenciado em Filosofia pela Faculdade Associada do Ipiranga e mestre em teologia pela Faculdade Nossa Senhora Assunção. Professor auxiliar de Teologia Sistemática na Faculdade Nossa Senhora Assunção e na Escola de Teologia Dominicana. Tutor de Antropologia Teológica no Centro Universitário Claretiano. Professor de Teologia Dogmática no Centro de Espiritualidade Teresiano. Assessor de Teologia Dogmática na CRB de São Paulo e Núcleo de Barretos. 